\title{
Effect of hydro-methanol stem bark extract of Burkea africana on erythrocyte osmotic fragility and haematological parameters in acetaminophen-poisoned rats
}

\author{
Terhemen Festus Swem ${ }^{1 *}$ D, Patrick Emeka $\mathrm{Aba}^{2}$ and Samuel Chukwuneke Udem²
}

\begin{abstract}
Background: Burkea africana is a widely used medicinal plant in folkloric medicine in many developing countries of the world. It is useful in the treatment of various ailments including hepatitis, jaundice, diarrhea, stomach aches, abscesses, oedema, epilepsy, bloody diarrhea, gonorrhea, syphilis, toothaches and poisoning. Nevertheless, there are little or no scientific evidence to substantiate this medicinal claim by traditional healers. Burkea africana stem bark was therefore, investigated for its protective or stabilizing effect on erythrocyte membrane in acetaminophentreated rats. B. africana stem bark was extracted using $80 \%$ methanol. Erythrocyte stabilizing effect was studied using erythrocyte osmotic fragility (EOF) test. Thirty (30) male rats were randomly assigned into five (5) groups of six (6) rats each. Groups 1 and 2 served as normal control and negative control (acetaminophen-treated group) respectively. Groups 3, 4 and 5 were pretreated with methanol stem bark extract of Burkea africana (MSBEBA) at doses of 200, 400 and $600 \mathrm{mg} / \mathrm{kg}$ body weight respectively once daily for seven (7) days. Blood samples were collected from the animals in all the groups on the 8 day for evaluation of packed cell volume, haemoglobin, red blood cell, white blood cell counts, and differential white blood cell count as well as erythrocyte osmotic fragility.

Results: The erythrocyte osmotic fragility test showed that there was a significantly $(p<0.05)$ low percentage hemolysis in the groups pre-treated with the extract when compared with the negative control. The percentage hemolysis was least at $600 \mathrm{mg} / \mathrm{kg}$ body weight of the extract. There was also a significant $(p<0.05)$ increase in the packed cell volume, haemoglobin, red blood cell count at all the doses of the extract used. Neutrophils were significantly $(p<0.05)$ decreased while lymphocytes were significantly increased in the groups administered MSBEBA 400 and $600 \mathrm{mg} / \mathrm{kg}$ body weight.

Conclusion: Methanol stem bark extract of Burkea africana had protective effect on the red blood cells and also improved haematological parameters. This indicates that Burkea africana may be useful in the treatment of disease conditions that results in hemolytic anemia by stabilizing red erythrocyte membranes and enhancing erythropoiesis.
\end{abstract}

Keywords: Burkea africana, Osmotic fragility, Haemolysis, Acetaminophen

\footnotetext{
* Correspondence: swemfestus422@gmail.com

'Department of Veterinary Physiology and Biochemistry, College of

Veterinary Medicine, Federal University of Agriculture, Makurdi, Benue State,

Nigeria

Full list of author information is available at the end of the article
}

() The Author(s). 2020 Open Access This article is licensed under a Creative Commons Attribution 4.0 International License, which permits use, sharing, adaptation, distribution and reproduction in any medium or format, as long as you give appropriate credit to the original author(s) and the source, provide a link to the Creative Commons licence, and indicate if changes were made. The images or other third party material in this article are included in the article's Creative Commons licence, unless indicated otherwise in a credit line to the material. If material is not included in the article's Creative Commons licence and your intended use is not permitted by statutory regulation or exceeds the permitted use, you will need to obtain permission directly from the copyright holder. To view a copy of this licence, visit http://creativecommons.org/licenses/by/4.0/. 


\section{Introduction}

Burkea africana (Wild seringa) is a flat-topped, small to medium deciduous tree, belonging to the family Ceaesalpiniaceae. It occurs widely in tropical and sub-tropical Africa $[10,19,45]$. It is a plant of high phyto-medicinal importance in Nigeria [10]. B. africana has been in use in traditional medicine in many African cultures [35]. The roots and leaves are most commonly used and have been found to be useful in the treatment of various ailments such as stomach aches, abscesses, oedema, epilepsy, bloody diarrhea, gonorrhea, syphilis, toothaches and poisoning [29]. The bark however is used more extensively as a decoction for treating headache, migraine, dizziness, pain, fevers, coughs, colds, catarrh, pneumonia, stomach obstruction, amenorrhoea, headaches, inflammation of tongue and gums, poisoning, skin diseases thrush and wounds $[18,29,35,36]$. B. africana has been found to have in-vitro anti-oxidant, antifungal, antibacterial and molluscicidal activities ([10, 14, 16, 18, 36]. It has been established that, $B$. africana has cytotoxic, antiproliferative and in-vitro anti-hepatotoxic effects [19, 45]. Methanol and aqueous stem bark extracts of $B$. africana have been found to contain a wide range of phytochemical constituents which include; flavonoids, alkaloids, tanins, cardiac glycosides, saponins, terpenoids, caumarins, phlobotanins, sterols and terpenes [10]. Proanthocyanidinns were also discovered in its stem bark with the two major components being fisetinidol-( $4 \alpha-8)$-catechin 3-gallate and bisfisetinidol-( $4 \alpha-6,4 \alpha-8)$-catechin 3-gallate [36]. The bark also contains $\beta$-sitosterol, Harman type alkaloids, tryptamin and also monomeric flavan-3-ols (catechin, epicatechin and fisetinodol) [36].

Oxidative stress caused by toxicants and xenobiotics generate free radicals, which are responsible for many disorders and complications associated with sickness [46]. Common amongst them is the lysis of red blood cells (RBC) due to lipid peroxidation of membrane lipids [4, 7], membrane deformity, cross-linking and fragmentation of proteins [3, 6, 7, 46]. Acetaminophen, a non-steroidal anti-inflammatory drug is a common cause of oxidative stress [43]. Acetaminophen overdosage results in hepatic damage as a result of the toxic effect of its metabolite Nacetyl-Para-benzoquinone imine (NAPQI) [37]. Glutathione conjugates with NAPQI in the liver to eliminate it, which leads to glutathione depletion in the presence of excess NAPQI. This is followed by binding of this metabolite to membrane proteins together with 3 '-Hydroxyacetanilide, a non-hepatotoxic isomer of acetaminophen [27, 37]. Oxidative stress induced by acetaminophen results from peroxidation of membrane lipids and mitochondria dysfunction which causes cell death [5,37]. The integrity of erythrocyte membrane, determines its functional status. Erythrocyte membranes are stable and durable under normal conditions [46]. Compromised erythrocyte membrane stability and durability is often associated with changes in fluidity and oxidative stress, in which case the lysis of RBCs is due to entrance of water into the cell $[46,49,51]$.

Erythrocyte osmotic fragility and osmotic stability are haematological parameters used in the evaluation of haemolysis in osmotic stress, which results in increased osmotic fragility or decreased osmotic stability [23, 24]. Fragility test is used as a measure of erythrocyte fragility which is helpful in disease diagnosis such as in spherocytosis and hemolytic crisis; and serves to augment the staining methods used in the evaluation of erythrocyte abnormalities in shape and size culminating into erythrocyte destruction $[23,30]$. It also provide information about membrane permeability and is used as a marker of membrane damage in disease conditions arising from toxicants and xenobiotic induced oxidative stress affecting erythrocyte [23, 46]. Fragility test has also being used for screening and monitoring of several disease conditions including $\alpha$ and $\beta$-thalassemia traits, hypertensive patients on diuretic and transportation stress [34, 38, 47]. Information on the effect of $B$. africana on the membrane integrity of erythrocytes is lacking. Therefore, this study was among other things aimed at evaluating the effect of methanol stem bark extract of B. africana (MSBEBA) on erythrocyte osmotic fragility in acetaminophen-treated rats.

\section{Materials and methods}

\section{Collection and identification of plant material}

Fresh stem barks of $B$. africana were collected in the wild in Ajaba village, Makurdi Local Government Area of Benue state, Nigeria in November 2017 and identified by Mr. Yeke Titus, a plant taxonomist of the Department of forestry, Federal University of Agriculture, Makurdi and a voucher specimen with the number UAM/FH/0326 was deposited in their herbarium.

\section{Preparation of extract from B. africana stem bark}

Stem bark of $B$. africana was air-dried at room temperature and pulverized using a grinding machine. The powdered plant material was stored in an air-tight polythene bags at room temperature until needed for the study. Extraction was done by cold maceration at room temperature, with $400 \mathrm{~g}$ of the powdered plant material soaked in $4 \mathrm{~L}$ of $80 \%$ methanol (20\% water and $80 \%$ methanol). The mixture was vigorously shaken at intervals $2 \mathrm{~h}$ during the day time. It was then filtered after 48 $\mathrm{h}$ using Whiteman filter paper size 1 . The filtrate was concentrated in vaccuo using rotary evaporator (Buchi, UK). The extraction ratio, crude to extract, was $1: 10 \mathrm{w} / \mathrm{v}$. The extract was stored in the refrigerator at $4{ }^{\circ} \mathrm{C}$ until required for use. 


\section{Experimental animals}

Albino rats weighing between 120 and $130 \mathrm{~g}$ were obtained from a private commercial farm in Nsukka, Enugu State. The rats were acclimatized in aluminum cages and housed in the animal house of the Department of Veterinary Physiology and Pharmacology, Faculty of Veterinary Medicine, University of Nigeria Nsukka for a period of 7 days. They were provided with clean drinking water and fed ad-libitum with commercially prepared poultry feed pellets $\left(\right.$ Topfeed $\left.^{\circ}\right)$, produced by Premier Feed Mill Nigeria (FMN). The experimental design used in this investigation was approved by the Ethical Committee of the Department of Veterinary Physiology and Pharmacology of the University of Nigeria Nsukka (Approval Reference Number: FVM-VPP-UNN-IACUC2018-039) with strictly adherence to good laboratory animal practice regulations of TDR [48] and the principles of laboratory animal use and care as enshrined by Natural research council [39].

\section{Median lethal dose $\left(\mathrm{LD}_{50}\right)$ estimation}

Median lethal dose $\left(\mathrm{LD}_{50}\right)$ was determined using acute toxic class (ATC) method as described in OECD 423 guideline $[40,44]$

\section{Osmotic fragility test}

Thirty (30) male rats, weighing $120-160 \mathrm{~g}$ were randomly assigned into five (5) groups of six (6) rats each. Groups 1 served as normal control and received only distilled water. Group 2 (negative control) was given distilled water for seven (7) days. Groups 3, 4 and 5 were pretreated with a $6 \%$ solution $(6 \mathrm{~g}$ of extract dissolved in $100 \mathrm{ml}$ of distilled water to give a concentration of 60 $\mathrm{mg} / \mathrm{ml}$ ) of MSBEBA orally at the dose of 200, 400 and $600 \mathrm{mg} / \mathrm{kg}$ body weight respectively once daily for seven (7) days. At day seven (7), groups 2, 3, 4 and 5 were administered acetaminophen (Paracetamol) at the dose of $2000 \mathrm{mg} / \mathrm{kg}$ body weight as a single oral dose. Blood samples were collected from the rats $48 \mathrm{~h}$ post administration of acetaminophen, through the retro-bulbar plexus into an ethylene diamine tetra-acetic acid (EDTA) bottles for osmotic fragility test and haematological analysis.

\section{Osmotic fragility test}

Osmotic fragility test was done using spectrophotometric method as described by Faulkner and King [20] and Adenkola and Oluremi [2]. The test examines the relationship between extent of haemolysis and osmolality (different concentrations of $\mathrm{NaCl}$ solution) in which the erythrocytes are suspended [20]. The concentration of liberated haemoglobin in each test medium is an index of the extent of osmotic haemolysis and the concentration of haemoglobin was determined using a spectrophotometer. The concentration of haemoglobin is directly proportional to the degree of haemolysis.

Six (6) different concentrations $(0.9 \%, 0.6 \%, 0.5 \%$, $0.4 \%, 0.3 \%$ and $0.0 \%)$ of sodium chloride $(\mathrm{NaCl})$ solutions were prepared and poured into six centrifuge tubes containing $10 \mathrm{ml}$ each respectively. The blood sample was mixed, to obtain a homogeneous suspension of blood cells and $0.1 \mathrm{ml}$ of blood is delivered into each of the 6 centrifuge tubes. They were mixed, allowed to stand for $20 \mathrm{~min}$ and centrifuged for $10 \mathrm{~min}$ at 3000 $\mathrm{rpm}$. The optical density (OD) of the supernatant was read at $546 \mathrm{~nm}$ using a spectrophotometer (CHEM-5 V3; Erba, Mannheim, Germany). The linear relationship between \% haemolysis and OD was plotted to generate a calibration curve, with $0 \%$ haemolysis $(0.9 \% \mathrm{NaCl})$ and $100 \%$ haemolysis $(0.0 \% \mathrm{NaCl})$, respectively. The Percentage haemolysis for each tube was then determined from the calibration curve and recorded.

\section{Determination of Haematological parameters}

Haematological parameters (Red blood cell (RBC) and white blood cell (WBC) counts, packed cell volume (PCV), haemoglobin concentration $(\mathrm{Hb})$ and differential WBC counts) were determined using standard laboratory procedures as described by Cheesbrough [15]. Haematological indices including; mean corpuscular volume (MCV), mean corpuscular haemoglobin $(\mathrm{MCH})$ and mean corpuscular haemoglobin concentration $(\mathrm{MCHC})$ were calculated from the values of $\mathrm{RBC}$ count, $\mathrm{PCV}$ and $\mathrm{Hb}[15]$.

\section{Statistical analysis}

Data from this study were analyzed using one-way analysis of variance (ANOVA) at $5 \%$ level of significance. Results were expressed as Mean \pm SEM. Duncan Multiple Range post hoc test was used to separate the variant Means using SPSS version 22.

\section{Results \\ Median lethal dose $\left(\mathrm{LD}_{50}\right)$ determination}

The MSBEBA did not cause any sign of toxicity or death on administration and was observed to be relatively non-toxic and safe at the test dose limit of $5000 \mathrm{mg} / \mathrm{kg}$ body weight after $48 \mathrm{~h}$. Therefore the $\mathrm{LD}_{50}$ of MSBEBA in rat was estimated to be above $5000 \mathrm{mg} / \mathrm{kg}$ body weight.

\section{Effect of MSBEBA pretreatment on erythrocytes osmotic fragility of acetaminophen-poisoned rats}

A dose dependent decrease in haemolysis was observed in the extract treated groups. In $0.6 \% \mathrm{NaCl}$ concentration, the percentage haemolysis of $18.44 \pm 2.39 \%$ was observed to be significantly $(P<0.05)$ lower at $600 \mathrm{mg} / \mathrm{kg}$ body weight when compared to the acetaminophen- 
treated group (Negative control) with $78.53 \pm 2.59 \%$ haemolysis. At $400 \mathrm{mg} / \mathrm{kg}$ body weight, haemolysis $(20.70 \pm 1.75 \%)$ was also significantly $(P<0.05)$ lower when compared to acetaminophen-treated group. Saline $(\mathrm{NaCl})$ solution of $0.5 \%$ concentration produced $95.65 \pm$ $0.87 \%$ haemolysis in acetaminophen-treated group which was significantly $(P<0.05)$ higher than the haemolysis in the treated group at $400 \mathrm{mg} / \mathrm{kg}$ and $600 \mathrm{mg} / \mathrm{kg}$ body weight of MSBEBA. Haemolysis increased steadily from $0.4 \%$ to $0.3 \% \mathrm{NaCl}$ in all treated groups, although there was still significant $(P<0.05)$ difference in haemolysis of treated group $600 \mathrm{mg} / \mathrm{kg}$ body weight of MSBEBA when compared with the normal control and acetaminophen group (Fig. 1).

\section{Effect of MSBEBA pretreatment on Haematological parameters of acetaminophen-poisoned rats}

There were no significant differences $(P<0.05)$ in the $\mathrm{PCV}$ and $\mathrm{Hb}$ values of all the extract-treated groups when compared with the normal control group. However, the mean PCV and $\mathrm{Hb}$ values of the acetaminophen-treated group were significantly $(P<$ 0.05) lower when compared with the normal control group (Table 1). Values of PCV; $41.00 \pm 1.10,44.20 \pm$ 1.16 and $43.20 \pm 1.50 \%$ and $\mathrm{Hb} ; 14.04 \pm 0.46,14.92 \pm 0.38$ and $14.04 \pm 0.22 \mathrm{~g} / \mathrm{dL}$ were significantly $(P<0.05)$ higher at all doses when compared with acetaminophen-treated group values of $34.75 \pm 0.25 \%$ and $12.00 \pm 0.10 \mathrm{~g} / \mathrm{dL}$ respectively. Red blood cell count of $8.24 \pm 0.16 \times 10^{12} / \mathrm{L}$ was significantly $(P<0.05)$ higher at $400 \mathrm{mg} / \mathrm{kg}$ body weight of the extract-treated group when compared with the acetaminophen-treated group value of $6.63 \pm 0.10 \times$ $10^{12} / \mathrm{L}$. The erythrocyte indices showed significant $(P<$ 0.05 ) increase in $\mathrm{MCH}$ of $20.74 \pm 0.60 \mathrm{Pg}$ at $200 \mathrm{mg} / \mathrm{kg}$ body weight of extract-treated group when compared with the acetaminophen-treated group $18.11 \pm 0.40 \mathrm{Pg}$. Total white blood cell count also showed no significant difference across all the groups except that at $400 \mathrm{mg} / \mathrm{kg}$ body weight extract-treated group with significantly $(P<$ $0.05)$ high value of $8.53 \pm 0.39 \times 10^{12} / \mathrm{L}$ when compared with acetaminophen-treated group value of $7.92 \pm 0.49 \times$ $10^{12} / \mathrm{L}$. lymphocyte count of $79.20 \pm 0.80 \%$ and $75.80 \pm$ $1.07 \%$ at 400 and $600 \mathrm{mg} / \mathrm{kg}$ body weight of extracttreated groups respectively were however increased significantly $(P<0.05)$ when compared with the acetaminophen-treated group value of $66.25 \pm 0.75 \%$. Significantly low neutrophil values of $22.80 \pm 1.32 \%$ and $24.60 \pm 0.24 \%$ were recorded at 400 and $600 \mathrm{mg} / \mathrm{kg}$ body weight when compared with the acetaminophen-treated group value of $35.00 \pm 1.00 \%$ (Table 1 ).

\section{Discussion}

This study investigated the effect of MSBEBA on erythrocyte osmotic fragility and haematological parameters of acetaminophen-treated rats. Methanol stem bark extract of B. africana appeared not to be harmful because it produced no toxicity signs even at the dose of $5000 \mathrm{mg} / \mathrm{kg}$ body weight. [32] stated that in the absence of mortality $24 \mathrm{~h}$ post administration of a substance or chemical at the dose of $5000 \mathrm{mg} / \mathrm{kg} \mathrm{b}$. wt, the substance

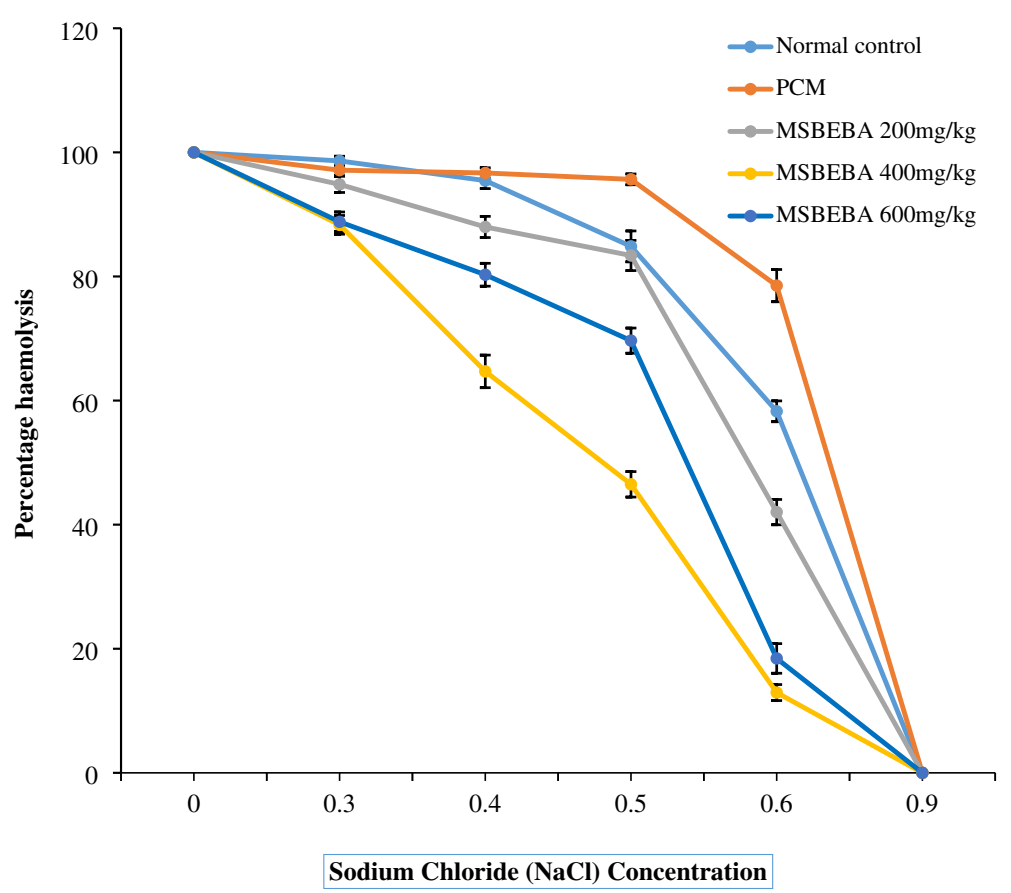

Fig. 1 Percentage erythrocyte osmotic fragility of acetaminophen-treated rats 
Table 1 Haematological parameters of acetaminophen-poisoned rats treated with MSBEBA

\begin{tabular}{|c|c|c|c|c|c|}
\hline \multirow[t]{2}{*}{ Parameters } & \multirow{2}{*}{$\begin{array}{l}\text { Normal } \\
\text { Control }\end{array}$} & \multirow[t]{2}{*}{ PCM Control } & \multicolumn{3}{|l|}{ MSBEBA + PCM } \\
\hline & & & $200 \mathrm{mg} / \mathrm{kg}$ & $400 \mathrm{mg} / \mathrm{kg}$ & $600 \mathrm{mg} / \mathrm{kg}$ \\
\hline$\overline{P C V}(\%)$ & $42.67 \pm 1.05^{b}$ & $34.75 \pm 0.25^{a}$ & $41.00 \pm 1.10^{b}$ & $44.20 \pm 1.16^{b}$ & $43.20 \pm 1.50^{b}$ \\
\hline $\mathrm{HB}(\mathrm{g} / \mathrm{dL})$ & $14.60 \pm 0.29^{b}$ & $12.00 \pm 0.10^{a}$ & $14.04 \pm 0.46^{b}$ & $14.92 \pm 0.38^{b}$ & $14.04 \pm 0.22^{b}$ \\
\hline $\operatorname{RBC}\left(\times 10^{12} / \mathrm{L}\right)$ & $7.55 \pm 0.24^{b}$ & $6.63 \pm 0.10^{\mathrm{a}}$ & $6.77 \pm 0.05^{\mathrm{a}}$ & $8.24 \pm 0.16^{c}$ & $7.13 \pm 0.15^{a b}$ \\
\hline $\mathrm{MCV}(\mathrm{FL})$ & $56.68 \pm 1.44^{\mathrm{ab}}$ & $52.45 \pm 1.13^{\mathrm{a}}$ & $60.60 \pm 1.61^{b}$ & $53.62 \pm 0.67^{a}$ & $60.63 \pm 2.19^{b}$ \\
\hline $\mathrm{MCH}(\mathrm{Pg})$ & $19.39 \pm 0.33^{\mathrm{ab}}$ & $18.11 \pm 0.40^{\mathrm{a}}$ & $20.74 \pm 0.60^{b}$ & $18.11 \pm 0.38^{\mathrm{a}}$ & $19.72 \pm 0.57^{\mathrm{ab}}$ \\
\hline $\mathrm{MCHC}(\mathrm{g} / \mathrm{dL})$ & $34.25 \pm 0.43^{a}$ & $34.54 \pm 0.25^{\mathrm{a}}$ & $34.24 \pm 0.60^{\mathrm{a}}$ & $33.78 \pm 0.53^{a}$ & $32.62 \pm 1.00^{\mathrm{a}}$ \\
\hline $\mathrm{TWBC}\left(\mathrm{X} / 10^{12} / \mathrm{L}\right)$ & $7.86 \pm 0.23^{\mathrm{abc}}$ & $7.92 \pm 0.49^{\mathrm{abc}}$ & $7.04 \pm 0.26^{\mathrm{a}}$ & $8.53 \pm 0.39^{b c}$ & $7.42 \pm 0.58^{\mathrm{ab}}$ \\
\hline Neutrophils (\%) & $33.83 \pm 0.40^{b c}$ & $35.00 \pm 1.00^{c}$ & $35.40 \pm 1.08^{c}$ & $22.80 \pm 1.32^{\mathrm{a}}$ & $24.60 \pm 0.24^{a}$ \\
\hline Lymphocytes (\%) & $66.50 \pm 0.50^{\mathrm{a}}$ & $66.25 \pm 0.75^{a}$ & $65.60 \pm 0.5^{\mathrm{a}}$ & $79.20 \pm 0.80^{c}$ & $75.80 \pm 1.07^{b}$ \\
\hline Eosinohpils (\%) & $0.83 \pm 0.40^{\mathrm{ab}}$ & $1.00 \pm 0.40^{b}$ & $0.20 \pm 0.20^{\mathrm{ab}}$ & $0.40 \pm 0.24^{\mathrm{ab}}$ & $0.20 \pm 0.20^{\mathrm{ab}}$ \\
\hline
\end{tabular}

Values are Mean \pm SEM. $n=6$. Values with different superscript on the same row are significantly $(P<0.05)$

is declared safe for practical purposes and considered to be of low toxicity, suggesting that the plant is safe for therapeutic use. OPPTS [41] and [21] further opined that such plant extracts or substances are toxicologically classified as category 4 or 5 agents. The stabilizing effect of methanol stem bark extract of B. africana on erythrocyte membranes was evident from the result of the osmotic fragility test. The plant extract used in this study significantly stabilized the erythrocyte membrane which is probably due to reduction in the peroxidation of membrane lipids induced by acetaminophen overdose. This was seen from the significant $(P<0.05)$ decrease in red blood cells' haemolysis in the extract-treated groups when compared with the acetaminophen-treated group (Fig. 1). The oxidative stress that usually results from acetaminophen over dose is due to the toxic effect of a highly reactive metabolite known as $N$-acetyl-P-benzoquinone imine, which is eliminated by conjugation of glutathione in the liver [33]. Excess of this metabolite causes the depletion of this endogenous antioxidant, glutathione resulting in lipid peroxidation, which deplete cellular lipids and proteins [33]. Therefore the cellular damage resulting from acetaminophen toxicity is as a result of lipid peroxidation and the exudation of cellular components like lysosomal enzymes [3, 4, 6, 7, 52]. Erythrocytes membrane integrity is compromised by oxidative stress which results in haemolysis $[1,6,9]$. The predisposing factors are the high content of polyunsaturated fatty acids in the membranes of red blood cells and the presence of oxygen and haemoglobin in the cells, which all enhance oxidation in tissues and cells $[6,50]$. Haemolysis caused by hypotonic saline solution was ameliorated more at $600 \mathrm{mg} / \mathrm{kg}$ body weight of the extract. This positive effect observed was probably as a result of the extract acting as an antioxidant or membrane stabilizer. B. africana stem bark have been shown to have antioxidant properties in an in-vitro study by
Mathisen et al., [36] and Cordier et al., [16], and have been known to contain phytochemical which possess antioxidant activities including phenols, flavonoids and alkaloids [10, 16]. Effective maintenance of erythrocyte membrane integrity has also been achieved by the use antioxidants such as vitamin $\mathrm{C}$ (ascorbic acid) in stress conditions $[3,6]$. The $B$. africana stem bark has also been shown to possess antioxidant properties $[8,11]$. Celine et al., [13] and [25] observed that, antiinflammatory drugs also stabilize erythrocyte membrane, by reducing methaemoglobin more than deoxyhaemoglobin. Therefore MSBEBA may have exerted its antihaemolytic activity by suppressing the consumption of glutathione in the liver and generation of oxidants which results in oxidative stress and ultimately cause damage to the cells.

Acetaminophen toxicity manifests with varying effects on the haematology of rats and has been shown to have effect on both red and white blood cells at the dose of $2000-3000 \mathrm{mg} / \mathrm{kg}$ body weight as a single dose [22, 26, 28]. Pre-treatment with MSBEBA significantly improved $(P<0.05)$ the values of PCV, haemoglobin, RBC count at the dose of 200,400 and $600 \mathrm{mg} / \mathrm{kg}$ body weight of MSBEBA suggesting that $B$. africana may have stimulatory effect on haematopoiesis. B. africana may be useful in the treatment of disease conditions that results in anaemia such as drug induced toxicosis, viral or bacterial hepatitis as well as other infectious diseases. The mean corpuscular volume (MCV) was also significantly increased at the dose of 200 and $600 \mathrm{mg} / \mathrm{kg}$ body weight of MSBEBA indicating the presence of haemtopoietic activity. Increase in MCV is an indication of the presence of erythropoietic cells that are bigger than the normal cells, which is seen in cases of responsive anaemia where immature RBCs are released into circulation [17]. However there was a significant $(P<0.05)$ reduction in neutrophil (neutropenia) in the groups administered 400 
and $600 \mathrm{mg} / \mathrm{kg}$ body weight of MSBEBA. This may be from the reaction of the experimental animals to stress or insult $[7,17]$. The significant increase $(P<0.05)$ in the lymphocyte (lympocytosis) at the dose of 400 and 600 $\mathrm{mg} / \mathrm{kg}$ body weight of MSBEBA, may also be as a result of stress and could be referred to as pseudolymphocytosis [17]. The reduction in haematological parameters of acetaminophen-treated group agrees with the study by O'Brien et al., [42] which stated that acetaminophen toxicity causes a reduction in blood cells as a result of the already established myelotoxic and lymphotoxic effects of acetaminophen $[12,31]$. The extract of $B$. africana may be said to have haematopoietic effect which suggests that the extract contains phytochemical constituents and or metabolites that have stimulatory effect on haematopoiesis. Therefore $B$. africana may be useful in the treatment of anaemia both haemolytic and non-haemolytic and in a case of acetaminophen toxicity and oxidative stress.

\section{Conclusion}

Methanol stem bark extract of B. africana had protective effect on the red blood cells and also improved haematological parameters. This indicates that $B$. africana may be useful in the treatment of disease conditions that results in hemolytic anemia by stabilizing red erythrocyte membranes and enhancing erythropoiesis.

\section{Abbreviations \\ ATC: Acute toxicity class; B. africana: Burkea Africana; EDTA: Ethylenediamine tetraacetic acid; EOF: Erythrocyte osmotic fragility; FMN: Feed mill of Nigeria; GHS: Globally harmonized system; Hb: Hemoglobin; MCH: Mean corpuscular hemoglobin; MCHC: Mean corpuscular hemoglobin concentration; MCV: Mean corpuscular volume; MSBEBA: Methanol stem bark extract of Burkea Africana; NAPQI: N-acetyl parabenzoquinone imine; \\ OECD: Organization for Economic Cooperation and Development; OPPTS: Office of prevention, pesticides and toxic substances; PCV: Packed cell volume; RBC: Red blood cell; WBC: White blood cell}

\section{Acknowledgements \\ This article is a segment of a Master dissertation. Full financial support was gotten from Tertiary Education Trust Fund (TETFund) academic staff sponsorship of the Federal University of Agriculture Makurdi, Benue State, Nigeria. We acknowlegde the staff of Department of Veterinary Physiology and Biochemistry and Department of Veterinary Physiology and Pharmacology of University of Nigeria Nsukka.}

\section{Authors' contributions}

TF carried out the research, analyzed the data and drafted the manuscript. PE interpreted the data, presented the data, and helped to the manuscript drafting. SU interpreted the results, and revised the manuscript. The author(s) read and approved the final manuscript.

\section{Funding}

This research was funded by Tertiary Education Trust Fund (TETFund) through the Federal University of Agriculture Makurdi.

\section{Availability of data and materials}

The datasets used and/or analyzed during the current study are available from the corresponding author on reasonable request.

\section{Ethics approval}

All applicable international, national, and/or institutional guidelines for the care and use of animals were followed.

\section{Consent for publication}

Not applicable.

\section{Competing interests}

The authors declare that they have no competing interests in this publication.

\section{Author details}

'Department of Veterinary Physiology and Biochemistry, College of Veterinary Medicine, Federal University of Agriculture, Makurdi, Benue State, Nigeria. ${ }^{2}$ Department of Veterinary Physiology and Pharmacology, Faculty of Veterinary Medicine, University of Nigeria, Nsukka, Enugu State, Nigeria.

Received: 7 December 2019 Accepted: 28 August 2020

Published online: 07 September 2020

\section{References}

1. Adam GO, Rahman MM, Lee SJ, Kim GB, Kang HS, Kim JS, Kim SJ. Hepatoprotective effects of Nigella sativa seed extract against acetaminophen-induced oxidative stress. Asian Pac J of Trop Med. 2016. https://doi.org/10.1016/j.apjtm.2016.01.039.

2. Adenkola AY, Oluremi OIA. Erythrocyte osmotic fragility and excitability score in rabbit fed hibiscus Sabdariffa in graded level. Niger J Physiol Sci. 2014:29(2):113-7.

3. Adenkola AY, Ayo JO, Sackey AKB, Adelaiye AB. Erythrocytes osmotic fragility of pigs administered antioxidant and transported by road for shortterm duration during the harmattan season. Afr J Biotechnol. 2010;9(2):226333.

4. Adenkola AY, Ayo JO. Effect of road transportation on erythrocyte osmotic fragility of pigs administered ascorbic acid during the harmattan season in Zaria, Nigeria. J of Cell and Animal Biol. 2009;3(1):4-8.

5. Adil M, Kandhare AD, Ghosh P, Venkata S, Raygude KS, Bodhankar SL. Ameliorative effect of naringin in acetaminophen-induced hepatic and renal toxicity in laboratory rats: role of FXR and KIM-1. Ren Fail. 2016;38(6):100720.

6. Ahur VM, Adenkola YA, Saganuwan SA, Ikye-Tor JT. Ameliorative properties of aqueous extract of Ficus thonningii on erythrocyte osmotic fragility induced by acetaminophen in Rattus norvegicus. Vet Res Forum. 2013;4(4): 207-12.

7. Ahur VM, Madubunyi I, Adenkola AY, Udem SC. The effect of ethyl acetate extract of Ficus thonningii (Blume) leaves on erythrocyte osmotic fragility and haematological parameters in acetaminophen-treated rats. Comp Clin Path. 2012. https://doi.org/10.1007/s00580-010-1107-1.

8. Al-Jaber NA, Awaad AS, Moses JE. Review on some antioxidant plants growing in Arab world. J of Saudi Chem Soc. 2011. https://doi.org/10.1016/j. jscs.2011.07.004.

9. Ambali SF, Ayo JO, Ojo SA, Esievo KAN. Ameliorative effect of vitamin C on chronic chlorpyrifos-induced erythrocyte osmotic fragility in Wistar rats. Hum and Exp Toxicol. 2011. https://doi.org/10.1177/0960327110368415.

10. Amom T, Vershima J. Phytochemical evaluation and antibacterial activity : a comparison of various extracts from some Nigerian trees. Peak J of Med Plant Res. 2013;1(2):13-8

11. Atawodi SE. Antioxidant potential of African medicinal plants. J Biotechnol. 2005;4(February):128-33.

12. Bergman $\mathrm{K}$, Muller $\mathrm{L}$, Teigen $\mathrm{SW}$. Series: current issues in mutagenesis and carcinogenesis, no. 65. The geno-toxicity and carcinogenicity of paracetamol: a regulatory (re)view. Mut Res. 1996;349:263-88.

13. Celine V, Tabassome S, Richard BK. Personalized medicine and anti-platelet therapy: ready for prime time. Eur Heart J. 2009;30(16):1943-63.

14. Chanda S, Dave R. In vitro models for antioxidant activity evaluation and some medicinal plants possessing antioxidant properties: An overview. AfrJ Microbiol Res. 2009. https://doi.org/10.1007/s13197-011-0276-5.

15. Cheesbrough M. Haematological tests. In: District laboratory practice in tropical countries. Part 2. Second edition. Cambridge: Cambridge University Press; 2006. p. 268-347.

16. Cordier W, Gulumian M, Cromarty AD, Steenkamp V. Attenuation of oxidative stress in U937 cells by polyphenolic-rich bark fractions of Burkea 
africana and Syzygium cordatum. BMC Compl and Alter Med. 2013. https:// doi.org/10.1186/1472-6882-13-116.

17. Cossio MLT, Giesen LF, Araya G, Pérez-Cotapos MLS, Vergara RL, Manca M, et al. Schalm's veterinary haematology. 6th ed; 2012.

18. Diallo D, Marston A, Terreaux C, Touré Y, Smestad Paulsen B, Hostettman K. Screening of Malian medicinal plants for fungicidal, larvicidal, molluscicidal, antioxidant and radical scavenging activities. Phytother Res. 2001;15:401-6.

19. Eboji O, Venables L, Sowemimo AA, Sofidiya MO, Koekemoer T, Van de Venter M. Burkea africana Hook (Caesalpiniaceae) ethanolic extract causes cell cycle arrest at M phase and induces caspase dependent apoptosis. South Afr J of Bot. 2017. https://doi.org/10.1016/j.sajb.2017.06.013.

20. Faulkner WR, King JW. Manual of clinical laboratory procedures. Cleveland: Chemical Rubber Company; 1970. p. 354.

21. GHS. Globally harmonized system of classification and labeling of chemicals. United Nations, New York and Geneva. 2005. ST/SG/AC.10/30/Rev.1.

22. Hodgman MJ, Garrard AR. A review of acetaminophen poisoning. Crit Care Clin. 2012. https://doi.org/10.1016/j.ccc.2012.07.006.

23. Igbokwe NA. A review of the factors that influence erythrocyte osmotic fragility. Sokoto J of Vet Sci. 2019. https://doi.org/10.4314/sokjvs.v16i4.1.

24. Igbokwe NA. Charactreization of the osmotic stability of Sahel goat erythrocytes in ionic and non-ionic hypotonic media, PhD Thesis. Nigeria: Department of Physiology, Pharmacology and Biochemistry, Faculty of Veterinary Medicine, University of Maiduguri; 2016. p. 1-219.

25. Igwe MC, Obeagu El. Determination of the Effect of Methanol Extract of Tetrapleura tetraptera Fruit Osmotic Fragility of Erythrocytes, Platelet Aggregation and Phospholipase A2 Activity. Ann Clin Lab Res. 2018;6(3): 250-5.

26. James LP, Mayeux PR, Hinson JA. Acetaminophen-Induced Hepatotoxicity Drug Metab Disp. 2003. https://doi.org/10.1124/dmd.31.12.1499.

27. Jaeschke H, McGill MR, Ramachandran A. Oxidant stress, mitochondria, and cell death mechanisms in drug- induced liver injury: Lessons learned from acetamino- phen hepatotoxicity. Drug Metab Rev. 2012;44:88-106.

28. Juma KK, Joseph NJN, David MN. Journal of Drug Metabolism and A Review of the Biochemical, Haematological and Histological Modulations in Acetaminophen Induced Hepatoxicity and the Potential of Urtica dioica in the Regeneration of the Liver. J of Drug Metab Toxicol. 2015. https://doi. org/10.4172/2157-7609.1000182.

29. Ken F, Ajina F, Richard M. Burkea africana - useful tropical plants. 2017; Retrieved from http://tropical.theferns.info/viewtropical.php?id=Burkea+ africana.

30. Kolanjiappan K, Manoharan K. Measurement of erythrocyte lipids, lipid peroxidation, antioxidants and osmotic fragility in cervical cancer patients. Clin Chim Acta. 2002:326:143-9.

31. Lister CF, McLean AE. Inhibition of DNA synthesis by paracetamol in different tissues of the rat in vivo. Toxicol. 1997;1 16:49-57.

32. Lorke D. A new approach to practical acute toxicity testing. Arch Toxicol. 1983:53:275-87.

33. Majee SK, Ramadhan MA, Monthe W. Long-term toxicological effects of paracetamol in rats. Iraqi J of Vet Sci. 2013;27(1):65-70.

34. Manju M, Anil J, Kishor D, Vinky R, Hemant K. Bias-corrected diagnostic performance of the naked eye single-tube red cell osmotic fragility test NESTROFT: an effective screening tool for beta- thalassemia. Hematol. 2006; 11(4):277-86.

35. Maroyi A. Burkea africana Hook. Record from PROTA4U. In: RHMJ L, Louppe D, Oteng-Amoako AA, editors. PROTA (Plant Resources of Tropical Africa/ Ressources végétales de l'Afrique tropicale). Wageningen; 2010. http://www. prota4u.org/search.asp >. Accessed 26 Oct 2018.

36. Mathisen E, Diallo D, Andersen ØM, Malterud KE. Antioxidants from the bark ofBurkea africana, an African medicinal plant. Phytother Res. 2002. https:// doi.org/10.1002/ptr.936.

37. Mcgill MR, Williams $C D$, Xie $Y$, Ramachandran A, Jaeschke $H$ Acetaminophen-induced liver injury in rats and mice: Comparison of protein adducts, mitochondrial dysfunction, and oxidative stress in the mechanism of toxicity. Toxicol Appl Pharmacol. 2012. https://doi.org/10. 1016/j.taap.2012.08.015

38. Minka NS, Ayo JO. Physiological responses of erythrocytes of goats to transportation and the mondulatory role of ascorbic acid. J of Vet Med Sci. 2010;72(7):875-81.

39. Natural Research Council of the National Academies. Guide for the care and use of laboratory animals: Committee for the Update of the guide for the care and use of laboratory animals Institute for Laboratory Animal Research Division on earth and life Studie. 8th ed. Washington, D.C.: The National Academies press; 2011. p. 1-213.

40. OECD. Acute Oral Toxicity -Acute Toxic Class Method. 2001. Test No. 423. Adopted 17th December, 2001.

41. Office of prevention, pesticides and toxic substances (OPPTS). Enviromental protection Agency, Health Effects Test Guidelines 870.1100. Acute Oral Toxicity. FPA. 2002;712(C):02-190.

42. O'Brien PJO, Swain A, Birmingham JM, Greenhill RW, Elcock F, Bugelski PJ. Repeated acetaminophen dosing in rats : adaptation of hepatic antioxidant system. Hum Exper Toxicol. 2000;19:277-83.

43. Pandit A, Sachdeva T, Bafna P. Drug-Induced Hepatotoxicity : A Review. J of Appl Pharm Sci. 2012. https://doi.org/10.7324/JAPS.2012.2541.

44. Saganuwan AS. A modified arithmetical method of reed and Muench for determination of a relatively ideal median lethal dose $\left(L_{50}\right)$. Afr J Pharm. 2016;5(12):1543-6

45. Schroeder I. A mechanistic study of organochlorine hepatotoxicity, University of Pretoria; Faculty of Health Sciences; Department of Pharmacology; 2011. p. 1-147.

46. Sharma B, Rai DK, Rai PK, Rizvi SI, Watal G. Determination of erythrocyte fragility as a marker of pesticide-induced membrane oxidative damage. Advanced protocols in oxidative stress II: methods. Mol Biol. 2010;594(1): 123-8.

47. Sirichotiyakul S, Tantipalakorn C, Sanguansermsri T, Wanapirak C, Tongsong T. Erythrocyte osmotic fragility test for screening of alpha-thalassemia-1 and beta- thalassemia trait in pregnancy. Intl J of Gynecol and Obste. 2004;86(3): $347-50$.

48. TDR (UNDP/World Bank/WHO special programme for research and training in tropical diseases) Good laboratory practices, quality practices for regulated non-clinical research and development. 2001. TDR/PRD/GLP/01.2.

49. Uzum A, Toprak O, Gumustas MK, Ciftci S, Sen S. Effect of vitamin E therapy on oxidative stress and erythrocyte osmotic fragility in patients on peritoneal dialysis and hemodialysis. J of Nephrol. 2006;19(6):739-45.

50. Vollard NB, Reeder BJ, Shearman JP, et al. A new sensitive assay reveals that hemoglobin is oxidatively modified in vivo. Free Radic Biol Med. 2005;39(9): 1216-28.

51. West IC. Radicals and oxidative stress in diabetes. Diab Med. 2001:47:171-80

52. Yücel R, Özdemir S, Darlyerli N, Toplan S, Akyolcu MC, Yiǧit G. Erythrocyte osmotic fragility and lipid peroxidation in experimental hyperthyroidism. Endocr. 2009. https://doi.org/10.1007/s12020-009-9251-6.

\section{Publisher's Note}

Springer Nature remains neutral with regard to jurisdictional claims in published maps and institutional affiliations.

\section{Submit your manuscript to a SpringerOpen ${ }^{\circ}$ journal and benefit from:}

- Convenient online submission

- Rigorous peer review

- Open access: articles freely available online

- High visibility within the field

- Retaining the copyright to your article

Submit your next manuscript at $\boldsymbol{\nabla}$ springeropen.com 